\title{
DEMOCRATIC ELECTIONS IN A GLOBAL CONTEXT
}

\section{P Tlakula}

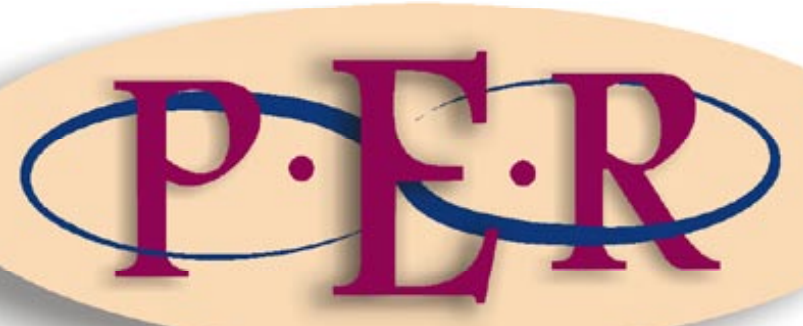

2007 Volume 2 


\section{DEMOCRATIC ELECTIONS IN A GLOBAL CONTEXT}

\section{P Tlakula*}

\section{$1 \quad$ Introduction}

There is agreement amongst political scientists and other scholars that there is a relationship between democracy, development and good governance. Democracy is a solid foundation for political and economic development. Democracy is also the best tool for managing social and economic conflict. There is also agreement that elections are central to the development of democracy in any country. Whilst elections on their own cannot guarantee development they are an important instrument through which all groups, including the most vulnerable, elect rulers of their choice. Once elected into power, these rulers assume the political power and authority to determine and shape national socio-economic policies and programmes that should result in better standards of living for the electorate whilst at the same time respond to the demands of economic globalisation. These rulers also decide on who forms the machinery of government, namely the executive, the judiciary, et cetera.

\section{Internationally recognised electoral standards}

The term 'legal framework for elections' refers to all legislation and pertinent material or documents which have a bearing on elections. A legal framework for elections will typically include the following sources:

a) Constitution;

* Adv Pansy Tlakula. Chief Electoral Officer: Electoral Commission of South Africa. Paper delivered at a colloquium on The Effect of Globalisation on the Development of Constitutionalism in Southern Africa, held on 26 October 2007 in Potchefstroom under the auspices of the Faculty of Law, North-West University, Potchefstroom and the Konrad Adenauer Foundation. 
b) Peace agreement;

c) Electoral law;

d) Other legislative acts dealing with other aspects of elections;

e) Rules and regulations;

f) Instructions and directives; and

g) Codes of conduct for political parties, for election officials and for election observers. ${ }^{1}$

Increasingly, over recent years, there has been growing consensus on what features constitute an acceptable legal framework for elections. Much of these generally acceptable frameworks for elections are based on international standards such as the 1948 Universal Declaration of Human Rights, the 1966 International Covenant on Civil and Political Rights, the 1981 African Charter on Human and People's Rights and the recently adopted African Charter on Democracy, Elections and Governance.

One other area of general agreement is that democratic elections constitute more than peaceful casting of ballots on the voting day. Elections which are internationally recognised as free, fair and credible have to pass several tests including the choice of electoral system, boundary delimitation, the independence of the electoral management body (EMB), media access to electoral processes and freedom of expression and information to name but a few. The role of the EMB - especially in developing democracies - is considered to be of critical importance.

\section{The Electoral Management Bodies (EMBs)}

\subsection{Models of Electoral Management}

Elections are often at the centre of conflict because of their centrality in changing the distribution of power. An EMB can either mediate or exacerbate 
this conflict by either managing a credible and legitimate election or by stagemanaging an election so that it produces a predetermined outcome rather than the true expression of the will of the people.

To address some of these issues, it is necessary that the management of the electoral process must be clearly defined in legal instruments. These instruments must contain provisions that promote full and informed participation in electoral events by political parties, the electorate and civil society organisations. $^{2}$

The legal framework must clearly spell out powers and functions of an EMB, protection of its members and staff against arbitrary dismissal by government, adequate definition of its relationship with external stakeholders etc. ${ }^{3}$ In other words, the legal framework must cover all electoral processes necessary for the delivery of a free, fair and credible result and for promoting the integrity of the entire process. ${ }^{4}$

For instance, in jurisdictions where an EMB is responsible for the delimitation of electoral district boundaries, the criterion for delimitation should be clearly determined and spelt out in the legal framework to protect an EMB from allegations of gerrymandering. Likewise, irrespective of who is responsible for the compilation and maintenance of the voters' list, an EMB must verify the accuracy and credibility of the voter's list that will be used at polling stations. ${ }^{5}$ This will eliminate ghost voters and underage voting. The legal framework must also spell out other processes such as registration and funding of political parties, registration and disqualification of candidates contesting an election, validation and announcement of election results, electoral observation, media coverage of political party campaigns, regulation of election campaigns and sanctions for non compliance and voter education and information where applicable. The legal framework can also contain provisions that address 
conflict of interest by EMB members and staff. For the legal framework to have the desired effect, all the provisions must be clear and unambiguous.

In addition to the legal framework, an EMB can also adopt policies and guidelines that will enhance the credibility of an electoral process. These policies and guidelines may address issues such as qualification and criteria for appointment of electoral staff, in particular at presiding and deputy presiding officer levels, training and competencies for electoral staff, availability and announcement of election results per polling station, et cetera.

There are three broad models ${ }^{6}$ of electoral management, namely the independent model, the government model and the mixed model. In terms of the independent model, elections are managed by an EMB which is institutionally independent from and is not accountable to the executive branch of government.

It may however be accountable to the legislature, the judiciary or the head of state. In the government model, elections are managed by the executive branch of government through a ministry. The EMB is accountable to a cabinet minister. The mixed model usually consists of two components, namely, a policy formulation, monitoring or supervisory function and the implementation function. The former function is usually performed by an EMB that is independent of the executive branch of government whilst the function of conducting elections is performed by a government department or division, for example, local government.

\subsection{Guiding Principles for an Election Management Body.}

Every EMB has the responsibility of ensuring the legitimacy, credibility and integrity of its electoral processes. Over the years, guiding principles have been 
developed internationally for election administration. These guiding principles include the following: ${ }^{7}$

- Independence

- Impartiality

- Integrity

- Transparency

- Efficiency and effectiveness

- Service-mindedness

- Professionalism

There is yet to be an agreement internationally on what constitutes an 'independent EMB'. This has been attributed to the fact that independence is normally viewed as consisting of two elements, formal and normative independence. ${ }^{8}$ Formal independence requires the independence of an EMB to be protected in the constitution or the law. Such constitution or law should also provide for the size, composition and membership tenure of an EMB as well as the appointment and removal procedure of its members. ${ }^{9}$ Normative independence on the other hand requires independence in decision making and functioning, in other words, independence in action, which in my view, is more important than formal or structural independence. Members of an EMB should perform their functions without being directed or influenced by any person, authority or political party. ${ }^{10}$ Functional independence also requires an EMB to be adequately and timeously funded. Preferably, the method of funding must be regulated by law. ${ }^{11}$

Impartiality requires an EMB to function impartially by treating 'all election participants equally, fairly and even-handedly, without giving advantage to any political tendency or interest group. ${ }^{12}$ For the purpose of establishing the integrity and credibility of electoral processes and to promote universal

7 IDEA 2006 Electoral Management Design http://www.idea.int/ 20 Nov at 22.

8 Ibid.

9 IDEA 2003 International Electoral Standards http://www.idea.int/ 20 Nov at 38.

10 Ibid at 42.

$11 \mathrm{Ibid}$ at 40.

12 IDEA 2006 Electoral Management Design http://www.idea.int/ 20 Nov at 23. 
acceptance of election results, an EMB must operate without interference and perceptions or allegations of manipulation or bias. ${ }^{13}$

The guiding principle of integrity means safeguarding the integrity of all electoral processes by ensuring that laws and regulations are in place that will make it possible for action to be taken against all those who breach electoral laws, rules and codes of conduct, be they electoral officials or political parties. Such action must be followed by appropriate sanction. ${ }^{14}$

To enhance the credibility of the electoral process, an EMB must function transparently but must do so in a manner that will always safeguard its independence. In this regard, it is important for an EMB to consult and communicate with relevant stakeholders, in particular political parties, on electoral processes. ${ }^{15}$ Finally, an EMB must perform its functions efficiently, effectively and with utmost professionalism, and with due regard to the needs of the electorate. This means that it should manage elections cost effectively, yet competently. Electoral staff must be properly trained in electoral processes. Inadequate training, coupled with unprofessional behaviour of electoral officials lead to inefficiency in the organisation of elections and this is often confused with corruption and fraud which may lead to the whole electoral process being discredited. $^{16}$

\subsection{The Electoral Commission of South Africa}

The Electoral Commission of South Africa was established as a result of the country's political transition. I think it is highly regarded as an EMB within and outside the country. To this end, the commission regularly hosts visiting EMBs from other countries and has been invited to participate in various technical assistance missions in countries such as the Democratic Republic of Congo, the Comoros, Lesotho, Namibia and Zambia.

14 IDEA 2006 Electoral Management Design http://www.idea.int/ 20 Nov at 24.

15 IDEA 2003 International Electoral Standards http://www.idea.int/ 20 Nov at 43.

16 IDEA 2006 Electoral Management Design http://www.idea.int/ 20 Nov at 24-25. 
On 10 December 1996, former President Nelson Mandela signed into law the Constitution of the Republic of South Africa, 1996. This brought to a close a long and bitter struggle against apartheid. As stated in the preamble to this constitution, through its adoption, the people of South Africa committed themselves to -

...heal the division of the past and establish a society based on democratic values, social justice and fundamental human rights: lay the foundation for a democratic and open society in which government is based on the will of the people and every citizen is equally protected by law; improve the quality of life of all citizens and free the potential of each person... ${ }^{17}$

This Constitution is founded on the following values: human dignity, the achievement of equality and the advancement of human rights and freedoms; non-racialism and non-sexism; supremacy of the constitution and the rule of law; universal suffrage, a national common voters' roll, regular elections and a multi-party system of democratic government to ensure accountability, responsiveness and openness. ${ }^{18}$

The Constitution further establishes the Electoral Commission of South Africa, which together with other institutions, is tasked to strengthen and support constitutional democracy. ${ }^{19}$ The independence of the Electoral Commission is guaranteed and protected by the Constitution which provides in this regard that it is independent, and subject only to the Constitution and the law, and that it must be impartial and must exercise its powers and perform its function without fear, favour or prejudice. The Constitution also calls upon organs of state to assist and protect the commission to ensure its independence, impartiality, dignity and effectiveness. Furthermore, all persons and organs of state are prohibited from interfering with the functioning of the commission. The independence of the commission is further strengthened by the fact that it is accountable to the National Assembly and not to the Executive.

17 Preamble of the Constitution of the Republic of South Africa 1996; hereinafter referred to as the Constitution.

$18 \mathrm{~S} 1$ of the Constitution.

19 S 181 of the Constitution. 
The commission consists of five members, one of whom is a judge. To engender public confidence in the commission, the appointment procedure of members of the commission is transparent. Moreover, the Constitution recommends the involvement of civil society in the recommendation process of members of the commission. ${ }^{20}$

The appointment procedure for the members of the Electoral Commission also ensures their impartiality. A person who holds a high political profile at the time of appointment is disqualified from appointment as a member of the commission. ${ }^{21}$ The names of candidates are solicited from the general public and the selection process is managed by an open and representative panel consisting of the Chief Justice, who chairs the panel, representatives of the Commission on Gender Equality, the South African Human Rights Commission and the Public Protector. ${ }^{22}$ The panel calls for public nominations, compiles a short list and conducts public interviews of the short listed candidates, and thereafter makes its recommendations to a committee of the National Assembly. This committee will in turn make recommendations to the National Assembly which must approve the recommended candidates by a resolution adopted with a supporting vote of a majority of members. The panel is required by law to act in accordance with the principle of transparency and openness and to make its recommendation with due regard to a person's suitability, qualifications and experience. ${ }^{23}$ The formal appointment is then made by the President of the country. A member of the commission can only be removed from office by the President if the National Assembly has adopted a resolution calling for that member's removal.

20 S 193 (6) of the Constitution.

21 S 6(2)(b) of the Electoral Commission Act 51 of 1996; hereafter the Electoral Commission Act.

$22 \mathrm{~S} 6(3)$ of the Electoral Commission Act.

$23 \mathrm{~S} 6(5)$ of the Electoral Commission Act. 


\section{$4 \quad$ The electoral system}

There are many electoral systems throughout the world and there is little consensus as to which promotes democratic governance and political stability. It is preferable for each country to choose a model that best suits its particular conditions, history and political context, but that will also contribute towards the deepening of democratic governance.

Very few states in Africa have taken a deliberate effort to redesign their electoral systems in a manner that addresses immediate challenges of their democratic imperatives such as accountability, representation and political stability. Some African states still use electoral systems that are part of the inherited political arrangements left behind by the departed colonial regimes. Some of these systems are very expensive and have no relevance to the contemporary social, economic and political challenges of the country.

In the interim constitution of $1994^{24}$ South Africa adopted a pure proportional representation system $(\mathrm{PR})$ as its electoral system for national elections subject to it being reviewed after the adoption of the final constitution. In 2003, Cabinet appointed a task team to discuss and make recommendations whether this system should be retained or not. I had the privilege of serving on the task team. The task team adopted criteria that served as guidelines for an appropriate electoral system, namely, inclusiveness, simplicity, legitimacy, fairness and accountability. Some members of the task team were of the view that the pure PR system meets all these requirements except accountability. So as to improve the accountability of elected representatives, they suggested that a component of multi member constituencies should be added to the current system. The choice of the electoral system in 1994 was informed by the spirit and values of our Constitution, namely equality, multi party democracy and universal adult suffrage amongst others. In my opinion the current system assists us to achieve these values. It assists us to achieve our commitment to the value of equality in that it ensures that the formation of political parties is 
based on national concerns and shared constitutional values rather than entrenched ethnic or racially exclusive interests. In a country with a history such as ours, it is important to have a system that will not exacerbate the remnants of racial and ethnic divisions that still exist in our society. This system assists us to achieve the value of universal adult suffrage in that it is accessible to both political parties and the electorate. It also enables as many parties as possible to participate in an election. This in turn enhances voter turnout and enthusiasm in the sense that voters are more likely to participate in an election if there are parties that they can strongly identify with. For the reasons stated, our Parliament decided to retain the PR system. One of the questions that each country has to confront when it embarks on constitutional and legislative reforms is whether its electoral system continues to serve its democratic interests and challenges.

\section{Technology as a tool for enhancing professional management of elections}

In the modern day of advanced technology, information technology (IT) can be used beyond providing support to business processes and can also provide environments and technologies that would enable an EMB to deliver services professionally, efficiently and effectively at all levels.

Central to the planning process in the run-up to the 2004 and 2006 local government elections in South Africa, was the system readiness project that focused on the upgrading or development of electoral applications. We made extensive use of technology to greatly enhance our ability to communicate with the electorate. In this regard we used the mobile phone technology to communicate with the voters and the following services were available on mobile phones through the use of short text messages: confirmation of registration status or details, voting station monitoring and election results, to mention a few. To give an example, the voting station monitoring tool was designed to allow the presiding officer to make use of a mobile phone text message to communicate with head office on voting day that their voting station 
had opened or closed. We also developed a good results system that allowed over 1,000 users to capture in excess of 33,000 results simultaneously from different locations. This enabled us to announce the results in three days after voting day compared to six days in 1999. The results were universally accepted by all political parties. I also have to mention that that this system enabled political parties to access election results by voting station immediately after they had been captured and verified by independent auditors. The public could also access results through the SMS facility. These initiatives caused the public to have confidence in the Electoral Commission's ability to manage fairly credible and professional elections.

Whilst the use of technology can enhance the ability of any electoral management body to deliver an efficient election, we must always ensure that the technology that we choose does not in any way affect the credibility of an election.

\section{$6 \quad$ The political parties}

In any democracy political parties are at the centre stage of political life. They play a pivotal role in founding and consolidating democratic systems of governance. Attempts to build a democracy without viable political parties have failed. Political parties play a vital role in the market place of political ideas and programmes. They are major vehicles for the recruitment of political leadership, the structuring of electoral choice, and the framing of policy alternatives. Parties are the principal players in electoral contests. To that extent, they are indispensable to democracy.

Political parties mediate between civil society and those who implement decisions in government and administration. They mobilise voters to participate in an election, recruit political personnel, aggregate a plurality of interests into a reasonable number of policy options and transform those policy options into political decisions. They provide citizens with an opportunity to choose from different "menus" of programmes. They communicate and legitimate the 
system's political processes back to the local level. Parties are important instruments in encouraging citizens' participation in the political process. Electoral reforms cannot take place if political parties do not accompany the process and also embrace it.

The essential role played by South African political parties as mediators in a difficult transition from the divisive apartheid past and in ushering and nurturing the democratic political process, permitting the expression and reconciliation of different views and interests, and facilitating the translation of the outcome of this process into law and public policy is commendable. The Electoral Commission's efforts went a long way in managing this process.

\subsection{Party Liaison Committees}

One of the ways through which these efforts crystallised was the creation of the system of Party Liaison Committees (PLCs), with the sole purpose to manage political pluralism and generate cooperation and trust between diverse political elements.

The Political party liaison structures are established in terms of the Electoral Commission $\mathrm{Act}^{25}$ which enjoins the commission to establish and maintain liaison and co-operation with parties. We have established these structures at national, provincial and local levels and are used as vehicles for consultation between the Electoral Commission and political parties on all electoral processes, and have proved to be a great success. Parties that are represented in the National Assembly, Provincial Legislation and Municipal Councils are members of PLCs.

For example, before an election, we submit the names of prospective presiding and deputy presiding officers to PLCs and members can object against appointment of any of the proposed persons on the ground of, amongst others, political partiality. We also consult PLCs on proposed amendments of electoral 
legislation and regulations. We further consult them on the development of the result system and invite their input on improvements. It has to be mentioned though that consultation does not mean we have to agree with their views. This system has become a model we use as our benchmark in promoting transparency and building trust between ourselves, political parties, and the general public. Political parties themselves have also benefited from this system in avoiding inter-party antagonism. Through these committees both small parties and big parties participate in an open forum on an equal footing. During non-election periods we hold PLC meetings bi-monthly. After proclamation of the election date, meetings are held once a week.

On Election Day we hold meetings twice a day or upon request by any party to resolve disputes that arise in various parts of the country. The PLC system works wonderfully in deepening democratic practices of participation from various political groupings. This working partnership between the Electoral Commission and political parties has been an important contribution to building political trust and confidence in South Africa.

\subsection{The Code of Conduct}

In addition, the Electoral Act has a Code of Conduct whose purpose is -

to promote conditions that are conducive to free and fair elections, including tolerance of democratic political activity; and free political campaigning and open public debate. ${ }^{26}$

The genius of this Code of Conduct is that it is enforceable by law:

Subject to this Act and any other law, the chief electoral officer may institute civil proceedings before a court, including the Electoral Court, to enforce a provision of this Act or the Code. ${ }^{27}$

Every registered political party and every candidate has to comply with this Code.

26 See s 99, sch 2 of the Electoral Act 73 of 1998; hereafter the Electoral Act.

27 See s 95(1) of the Electoral Act. 
The Code of Conduct forms the basis for favourable participation in electoral processes and clearly prohibits any form of intimidation. The basis of the Code flows clearly from the Bill of Rights which encourages freedom of affiliation, speech, et cetera. It is essential that political parties monitor the electoral process, safeguarding against infringements of the law not only by electoral administrators, but also against one another. This forms an important integrity safeguard. It is part of the check and balance mechanisms that protect the viability and honesty of election administration and the participation by political parties and other interest groups. Even our own electoral staff members are required to sign a code of conduct at a public function, thus committing themselves to the pursuit of credible elections.

The effectiveness of the approach for our purposes can be judged by the fact that, compared to the 1994 elections when the Independent Electoral Commission (IEC) received 3,558 complaints concerning no-go areas, political violence and intimidation; in the 1999 elections the Electoral Commission received 1,032 complaints; and only about 108 in the 2004 elections.

\subsection{Political Party Funding}

The Constitution provides that -

to enhance multi party democracy, national legislation must provide for the funding of political parties participating in the national and provincial legislatures on an equitable and proportional basis. ${ }^{28}$

The funding of political parties is provided for in the Public Funding of Represented Political Parties Act 103 of 1997 (PFRPP). The fund consists of moneys appropriated to it by Parliament, contributions and donations to the fund originating from any source, whether within or outside the country, interest earned on moneys deposited or invested and moneys accruing to the fund from any other source. ${ }^{29}$ In terms of the PFRPP Act, the commission, through the Chief Electoral Officer is responsible for the management and administration of

$28 \mathrm{~S} 236$.

29 S 2(2) of the Public Funding of Represented Political Parties Act 103 of 1997; hereafter the PFRPP Act. 
the fund ${ }^{30}$ In terms of the PFRPP Act, only political parties that participate in parliament and provincial legislatures are eligible for funding. ${ }^{31}$ This is a source of contestation amongst new political parties who feel that the PFRPP Act favours existing and well established parties at the expense of the new ones.

\section{$7 \quad$ Other electoral standards}

Some of the other issues to consider are boundary delimitation, voter registration, freedom of expression, campaign financing, election observers, and compliance with and enforcement of the electoral law.

The framework for elections should ensure that:

a) Boundaries are delimited in such a way that they afford equal value to each vote in order to ensure effective representation;

b) The voters' roll is maintained in an accurate and transparent manner in order to protect the rights of voters and to prevent fraudulent registrations and the unlawful removal of names from the voters' roll;

c) All candidates and political parties should have reasonable access to the media and should be treated equitably by the public broadcaster;

d) All candidates and political parties should be treated equitably in terms of legal provisions for campaign finances;

e) Election observers can observe all stages of the election processes; and

f) There are effective mechanisms for compliance with the law and the enforcement of electoral rights. 


\section{Conclusion}

Most countries on the African continent have established or are in the process of establishing independent EMBs and are also looking at the reform of their electoral legislation and framework in order to enhance the credibility, integrity and legitimacy of their electoral processes. These developments must be encouraged and applauded. At the same time however, there is an emergence of new challenges that have to be addressed. These challenges include firstly the undemocratic manner in which political parties seem to be functioning internally. This normally results in factionalism which in turn affects the candidate nomination process, particularly in jurisdictions that use the PR system.

Secondly, the problem of money in politics, especially as it relates to the absence of legislation in many countries that regulates funding of political parties, particularly private funding and disclosure of sources of funding. This has resulted in some political parties or candidates being funded with 'blood money' and also using money to 'steal the election'.

Thirdly, the so called "incumbency" that is the use of state resources by the ruling party in election campaigns is one of the emerging issues that we all have to grapple with. Although most countries have laws that are supposed to regulate these matters, for some reason these laws do not seem to be adhered to.

Fourthly, attacks on freedom of expression seem to be on the increase on our continent. This takes the form of harassment, intimidation and unlawful arrest and detention of media practitioners and opposition political parties in the runup to an election.

Finally, the visibility of political parties between elections is another challenge. As some writers aptly put it:

Are African political parties sleeping ghosts that wake up to haunt the goodwill and political resources of the electorates only during 
election year(if not month) or during election campaigns? Or are they maintaining vigilance and playing their role in democratic governance as the link between citizens, parliament and government? ${ }^{32}$ 


\section{Bibliography}

Tlakula "Democratic Elections in a Global Context"

Tlakula P "Democratic Elections in a Global Context" in The Effect of Globalisation on the Development of Constitutionalism in Southern Africa Paper delivered at a colloquium under the auspices of the Faculty of Law, North-West University and the Konrad Adenauer Foundation on 26 October 2007 Potchefstroom

\section{Register of legislation}

Constitution of the Republic of South Africa 1996

Constitution of the Republic of South Africa Act 200 of 1993

Electoral Commission Act 51 of 1996

Electoral Act 73 of 1998

Public Funding of Represented Political Parties Act 103 of 1997

\section{Register of international standards}

African Charter on Democracy, Elections and Governance 2007

African Charter on Human and People's Rights 1981

International Covenant on Civil and Political Rights 1966

Universal Declaration of Human Rights 1948

\section{Register of Internet resources}

IDEA 2003 International Electoral Standards http://www.idea.int/ 20 Nov International Institute for Democracy and Electoral Assistance International Electoral Standards: Guidelines for Reviewing the Legal Framework of Elections [Found on internet] http://www.idea.int/publications/ies/index.cfm [Date of use 20 November 2007]

IDEA 2006 Electoral Management Design http://www.idea.int/ 20 Nov International Institute for Democracy and Electoral Assistance Electoral Management Design: The International IDEA Handbook [Found on internet] http://www.idea.int/publications/emd/index.cfm [Date of use 20 November 2007] 
IDEA 2007 Political Parties in Africa http://www.idea.int/ 20 Nov International Institute for Democracy and Electoral Assistance Political Parties in Africa: Challenges for Sustained Multiparty Democracy [Found on internet] http://www.idea.int/publications/pp_africa/index.cfm [Date of use 20 November 2007]

\section{List of abbreviations}

$\begin{array}{ll}\text { EMBs } & \text { Electoral Management Bodies } \\ \text { IDEA } & \text { Institute for Democracy and Electoral Assistance } \\ \text { IEC } & \text { Independent Electoral Commission } \\ \text { IT } & \text { information technology } \\ \text { PFRPP } & \text { Public Funding of Represented Political Parties Act } \\ \text { PLCs } & \text { Party Liaison Committees } \\ \text { PR } & \text { proportional representation system } \\ \text { S } & \text { section(s) } \\ \text { Sch } & \text { schedule(s) } \\ \text { SMS } & \text { short text messages }\end{array}$

